\title{
A Tribute to Ian McTaggart-Cowan, 1910-2010, O.C., O.B.C., PhD, LL.D, F.R.S.C.
}

\author{
Rod S. Silver, Neil K. Dawe, Brian M. Starzomski ${ }^{3}$, Katherine L. PARKer ${ }^{4}$, and David W. \\ NAGORSEN $^{5}$
}

\footnotetext{
${ }^{1}$ Director, The Nature Trust of BC, 4065 Beam Crescent, Victoria, British Columbia V8N 5 Y7 Canada

${ }^{2}$ President, Qualicum Institute, A society for ecological, social and economic sustainability, 438 Temple Street, Qualicum Beach, British Columbia V9P 1A3 Canada

${ }^{3}$ Ian McTaggart-Cowan Professor of Biodiversity Conservation and Ecological Restoration, School of Environmental Studies, Social Sciences and Math Building B225, 3800 Finnerty Road, Victoria, British Columbia V8P 5C2 Canada

${ }^{4}$ Ian McTaggart-Cowan Muskwa-Kechika Research Professor, Ecosystem Science and Management Program, University of Northern British Columbia, 3333 University Way, Prince George, British Columbia V2N 4Z9 Canada

${ }^{5}$ Mammalia Biological Consulting, 4268 Metchosin Road, Victoria, British Columbia V9C 3Z4 Canada
}

Silver, Rod S., Neil K. Dawe, Brian M. Starzomski, Katherine L. Parker, and David W. Nagorsen. 2010. A Tribute to Ian McTaggart-Cowan, 1910-2010, O.C., O.B.C., PhD, LL.D, F.R.S.C. Canadian Field-Naturalist 124(4): 367-383.

When Andy Stewart, a wildlife biologist with the BC Conservation Data Centre, went looking for historical information to include in the final volume of The Birds of British Columbia, he found, published in Mackie (1985:114), a letter written by Dr. Rudolph M. Anderson of the Canadian National Museum to naturalist Hamilton Mack Laing. The date was December 26, 1929. In part, it read:

\begin{abstract}
"There is another factor that enters into the plans. You are now about the only freelance collector in the West who is competent to do museum collecting, and is familiar with the technique, and, as an old apostle, we want you to help pass on some of the tradition to a disciple. We have a young man in view that has been recommended to me from several different sources. His name is Ian McTaggartCowan of North Vancouver, now a third year student at the University of BC. I met him at Winson's place in Huntingdon last fall, and Kenneth Racey and Allan Brooks spoke highly of him, also Professors Spencer and MacLean Fraser of the department of zoology at the University.

...They say his forebears were naturalists, and he has camped and hunted all his life. Spencer says he... is a go-getter in the field. I had only a short conversation with him last fall and was much taken by him.... I think that Cowan is the real thing...."
\end{abstract}

Ian McTaggart-Cowan was born in Edinburgh, Scotland in 1910 and immigrated to Canada at age three. The eldest of four, he developed an early interest in natural history, which was encouraged by his mother. That interest grew as he did. At age 12, he completed a one-year diary of all the birds he had seen around his North Vancouver home as a requirement for a proficiency badge in the Boy Scouts. Ian would later recall, "James A. Munro unknowingly gave me useful advice at a very early stage in my adventures with birds. In 1923, National Parks of Canada offered a book prize to any boy scout in Canada who achieved his Naturalist badge and submitted a bird diary covering a year of observation. I met the requirements, sent in my diary, and in time received a copy of Gordon Hewitt's book, The Conservation of Wildlife in Cana$d a$. This was my first introduction to wildlife conservation. I still have the volume, with its congratulation signed by J. B. Harkin, Director of the National Parks of Canada. I was impressed! Some days later a letter came from J. A. Munro, Federal Migratory Bird Officer. He had read my diary and, in a nice way, pointed out some mistaken identifications and fine points not covered in my library of one book (Chester A. Reed's Bird Guide). I wrote in reply asking more questions and received helpful answers. Of such small kindnesses new directions are born. Twenty-four years later Munro and I co-authored a book on the avifauna of British Columbia!" (Cowan 1998). Ian's bird diary was the beginning of a life-long obsession with observing, recording and writing about the wonders of the world around him.

While a first-year student at the University of British Columbia, he attended a lecture by Vancouver Natural History Society life member Kenneth Racey, hosted by the Burrard Field Naturalists. The topic was small mammals of the Lower Mainland. Ian was fascinated by Racey's knowledge of wildlife, his understanding of the rapidly changing natural world and his expertise in the use of techniques to study small mammals. Racey invited him to his house to see his collection and, recognizing Ian's enthusiasm, thereafter included him in many of the Racey family field trips, including outings to their summer home at Alta Lake. Racey and Cowan would publish The Mammals of the Alta Lake Region of Southwestern BC in 1936. 
Ian's first major publication, however, came in 1930 with The Mammals of Point Grey, a modest beginning to his over 550 works in print, on radio and on television that followed in the subsequent 80 years.

For Ian, 1930 also saw the beginning of total immersion in the adventures of becoming a vertebrate zoologist. He was appointed as field assistant to Hamilton Mack Laing, a naturalist, outdoor writer and photographer who collected wildlife specimens from Western Canada for the National Museum of Canada. Ian first worked for a month on the little known Tobacco Plains near Elko, British Columbia, then for three months in the Rocky Mountain National Parks of Jasper and Banff. It is here that Ian's initial biological studies of the fauna of the parks began.

The following year, Laing's expedition was cancelled as the depths of the Great Depression took hold and research monies vanished. Kenneth Racey was seriously ill in the winter of 1930-31, and in the spring, decided to take a few months away from his business to recuperate. He asked Ian to accompany him on an extended field trip. They spent May 1931 studying the birds and mammals in the Tofino area of Vancouver Island including the fascinating near-shore fauna, and the alpine assembly of creatures at the head of the Nanaimo River. The most important contribution of the Nanaimo River work was the rediscovery of the Vancouver Island Marmot, an animal not seen since 1911, when the type series was collected on the mountains above Port Alberni by an expedition from the Museum of Vertebrate Zoology, Berkeley. June was spent with the entire Racey family on Anarchist Mountain and in other locations in the southern Okanagan where a new mammal for British Columbia was discovered: the Pacific Pallid Bat. The expedition continued in July and August in the western Chilcotin and included a side trip by Racey into the unique "northern" habitats of the Itcha Mountains to see caribou. Ian acknowledged the extraordinary contribution that Racey made to his growth and understanding of wild landscapes and their vertebrates. Though a generation apart, Kenneth Racey became a life-long friend and in 1936, Ian's father-in-law.

In 1932, after graduating from the University of British Columbia with an undergraduate degree, Ian took a teaching fellowship at the University of California at Berkeley to begin his doctorate. There he had the opportunity to work under the guidance of noted ecologist Joseph Grinnell. While at home in British Columbia during the summer of 1933, a broken leg almost ended his doctoral studies because he was unable to report for duties as a teaching assistant. He found himself without an income to pay for fees and books for the autumn term. His year was saved by the generosity of Grinnell who accompanied his gift to Ian with some scholarly advice: "Now, no more foolishness about dropping out of your program because of a small shortfall. I don't want the money back-give it to some worthy student somewhere down your path. There will be many of them." Ian fondly remembers Grinnell for his kindness, and for providing a first glimpse of the dedication that good thesis advisors require in order to ensure the success of their graduate students.

Ian completed his doctorate at Berkeley in 1935. His doctoral thesis was on geographic variation and taxonomy of the mule and white-tailed deer genus, Odocoileus, of western North America. It was probably the first published document to include statistical treatment of big mammals, written at a time when the Canadian government still believed that game was unlimited and all predators should be shot. Ian returned to British Columbia to work as the first universitytrained biologist at the Provincial Museum in Victoria, then directed by Francis Kermode. As Corley-Smith (1989) noted, "Cowan had taken his training in the Museum of Vertebrate Zoology at Berkeley, at the time 'one of the great institutions of the world in terms of systematic collections. Even though the collections had been neglected, there was good basis for a fresh start' and Ian went about the task of reversing the years of neglect."

Cowan would recall, "my analysis of the situation was that, apart from cataloguing and curating the collections, the Museum's most important opportunity was in getting out into the province and studying the great diversity of living animals and plants to be found there."

Ian seized on that opportunity and initiated a series of systematic surveys of the vertebrates in different regions of the province through his own fieldwork and a network of naturalists and museum collectors. Possibly the most ambitious was a 3-year survey of the vertebrates on the remote coastal islands of the centralnorthern coast with Thomas McCabe, mostly sampled by fish boat. This tradition of biodiversity surveys by the Museum would carry on for many decades.

During his five years at the Museum, Cowan published more that 20 scientific papers, some through the Museum, and others in various scientific journals. In 1939, he initiated the Provincial Museum's Occasional Papers series with his monograph "The Vertebrate Fauna of the Peace River District of British Columbia". The series ran for 50 years with 26 Occasional Papers produced that covered various aspects of the province's natural history.

In 1940, he left the Museum for an appointment as Assistant Professor in the Department of Zoology, University of British Columbia, in Vancouver, but continued to work closely with Museum staff to collect, classify and describe the province's diverse fauna. Among the most successful collaborative projects was the publication of The Mammals of British Columbia in 1956 with close friend, former graduate student, and colleague Charlie Guiguet. In the following 22 years, this important reference book had seven printings and two 


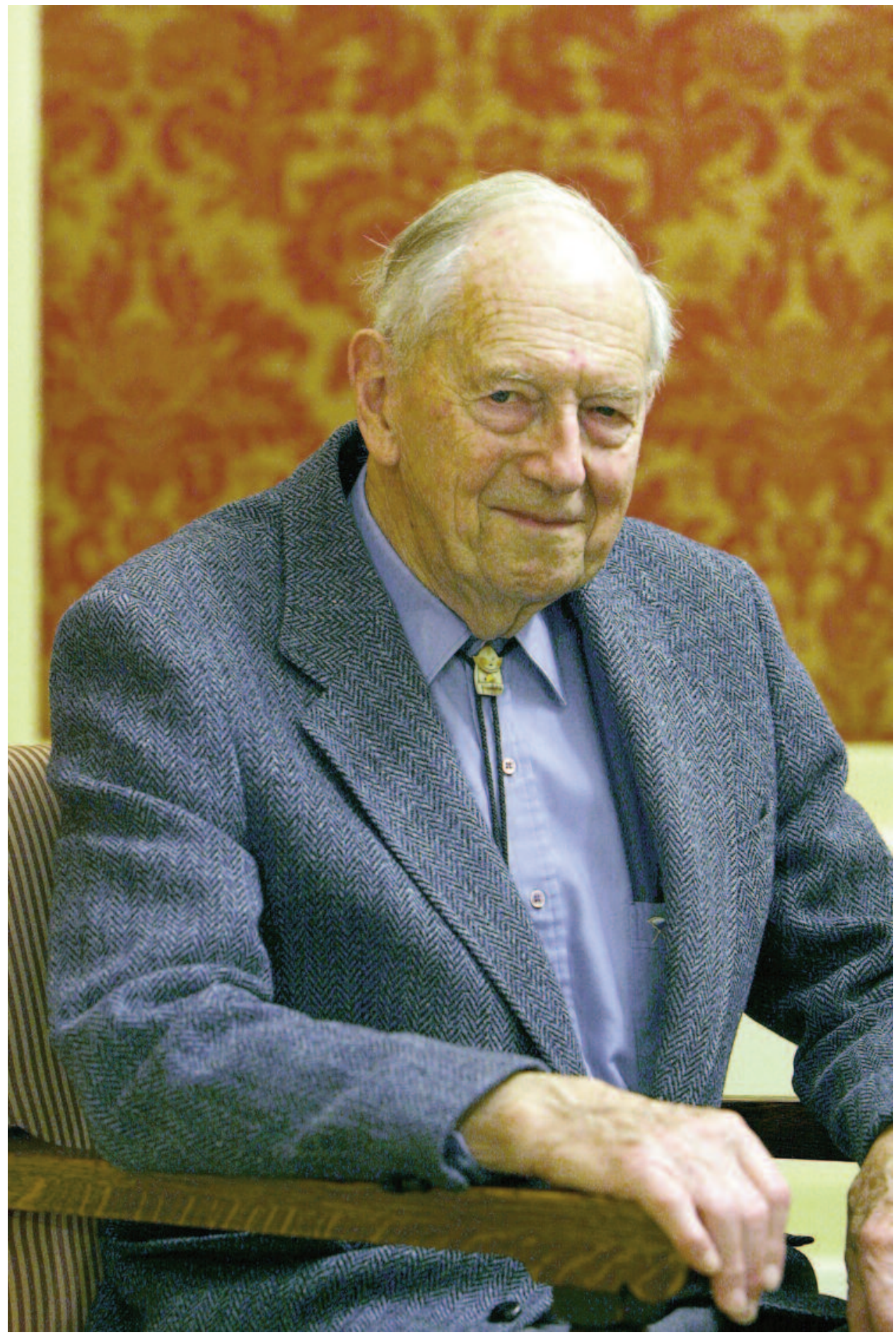

FIgURE 1. Ian McTaggart Cowan, October 2004 as Director Emeritus of the Nature Trust of British Columbia (Andrew Klaver, Nature Trust of British Columbia). 
minor revisions and was one of the most widely used and widely distributed handbooks the museum had ever published.

Ian appeared on the university scene at a most fortuitous time. The great graduate schools in the United States had discovered "ecology", and the graduates, of whom Ian was one, were making waves. The "field" sciences were in ferment.

In 1943, Ian was contracted by Parks Canada to undertake the first extensive field studies of the fauna of the Rocky Mountain Parks of Canada. He was a natural choice for the work because, through his threemonth stint in the parks with Mack Laing 13 years earlier, he was immediately at home in the landscape. His first guide was the legendary mountain man, James "Jimmy" Simpson, who provided safe passage to the most remote areas of the Rockies. "Jimmy taught me everything I couldn't get from books," said Ian in a 2005 interview with Briony Penn. "We climbed as high up every mountain as we could get, then would stop and use our field glasses to count, age and sex the animals as best we could. You never disturbed those animals, because if you did they'd get all mixed up, and forget it - your study is over."

Promoted to Professor of Zoology at UBC in 1945, he served as head of the department from 1953 to 1964. During this time he continued to develop and teach courses in vertebrate zoology. It was the first academic program in Canada to emphasize the biological basis of wildlife conservation. As well, Cowan was largely responsible for convincing Canadian governments to recruit trained wildlife biologists to staff their wildlife management agencies. He himself served as a scientific advisor to the BC Game Commission.

Ian was a prolific researcher and writer, achieving an impressive number of published scientific works. The scope of his efforts is unprecedented with work on both invertebrates and vertebrates. His papers on mammals ranged from shrews to whales, a scope unimaginable in today's world of specialization. However, his scientific papers made important contributions in other areas as well, such as the now neglected field of vertebrate taxonomy. His taxonomic revisions of the mule and white-tailed deer (1936), mountain sheep (1940), pikas (1954), and coastal populations of the deer mouse (1945) are important works still cited today and used as models for testing with the latest modern genetic methods.

The vertebrate zoology program at UBC was established around the personal specimen collections belonging to Ian and friend Kenneth Racey. Those collections are part of the over 40000 specimens known as the Cowan Vertebrate Museum, now part of the Beaty Biodiversity Museum at the University of British Columbia.

The 60s and early 70s were exciting times for students in the field sciences at UBC. In addition to Cowan and Mary Taylor in the zoology department, Ian's

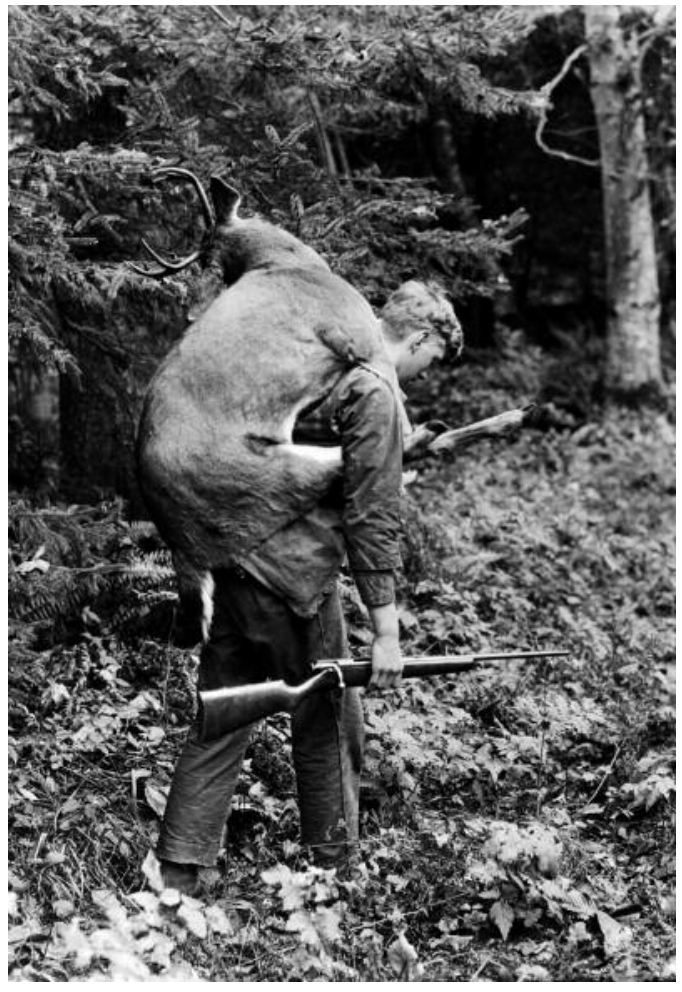

FIGURE 2. Ian with Black-tailed Deer, Constitution Hill, Vancouver Island, 1939 (Image B-01601 Courtesy of the Royal British Columbia Museum Archives) .

students often drew on the vast knowledge and guidance of top notch leaders in related disciplines such as Bert Brink in plant science, A. J. Wood in animal science, D. J. Laird in soil science, Vladimir Krajina and Kay Beamish in botany, Bill Matthews in geology, a young Fred Bunnell in forestry/wildlife and Peter Larkin and Bill Hoar in fisheries. McTaggart-Cowan's extensive bibliography clearly demonstrates his collaborative approach to exploring the many fascinating aspects of science.

Ian became Dean of Graduate Studies at UBC in 1964. Even with expanded responsibilities, he continued to teach a course in wildlife biology, supervise directed studies and guide the research of zoology doctoral candidates. "You would be surprised how much work you can get done in the quiet of 2 hours before the world wakes up," he told Rod Silver, explaining his habit of rising early to keep up with his interests.

Education was at the heart of McTaggart-Cowan's long career and he was phenomenally successful in influencing people, from politicians to children. He was an engaging and much sought after speaker. The key to teaching, he said, was to "identify the point where the audience will join you and engage themselves, even if they think you are wrong. Dogmatism turns people 
off. I tried to paint a picture of what a fascinating and dramatic world we live in. I like to explain to people the beautiful, fascinating things that I see. All my life I have tried to explain to colleagues, family, students, anyone who will listen to me, what a beautiful place I am looking at! It is not all sweetness and light, but this world is absolutely fascinating" (Penn 2005).

In all, Ian worked with over 100 graduate students and directly supervised a wide variety of research by some $23 \mathrm{PhD}$ and 20 Masters students. Perhaps Carl Linnaeus, the father of taxonomy said it best: "a professor can never better distinguish himself in his work than by encouraging a clever pupil, for the true discoverers are among them, as comets amongst the stars."

Some of his graduate students were indeed the new "comets" in the wildlife field. Names like Maurice Hornocker (mountain lions), Valerius Geist (mountain sheep), Charles Jonkel (bears), Fred Zwickel (Blue Grouse), and C.S. "Buzz" Holling (predation) quickly became associated with excellence in wildlife science in academic circles.

Geist recalls, "I knew Dr. Cowan as an intellect who quickly grasped unusual, new, complex concepts and appreciated such even if they ran afoul of conventional social norms. Homosexuality in mountain sheep was one such example. Realization that growth, development and bioenergetics were vital aspects in understanding mammals was another."

Other students such as Ian Stirling, Daryll Hebert, Dave Hatler, Steve Johnson, Charles Guiguet, Yorke Edwards, James Hatter, J. Bristol Foster and many others enjoyed equally successful careers in government and consulting.

Former student Dave Hatler no doubt spoke for students and colleagues alike in the dedication of his latest book:

\section{"To Ian McTaggart-Cowan, an extraordi- nary naturalist, remarkable biologist and as good a mentor as anyone could hope for" (Hatler et al. 2008).}

It is difficult to imagine any areas of terrestrial vertebrate zoology and wildlife conservation that have not been influenced by Ian's work. Long-time UBC contemporary and colleague, the late Bert Brink, agreed: "More than any others, Ian and his students have fostered knowledge of the fauna of the land and sea. I would stand by this choice (from the multitude of his accomplishments) as the most far reaching and significant: his field work was outstanding and global."

Indeed, Ian identified 15 new subspecies of vertebrates, and while in Australia he rediscovered the Mountain Pygmy-Possum that was previously known only from fossils (Campbell et al., in preparation).

It is little wonder then that Ian was often referred to as the "Dean of Vertebrate Zoologists" in Canada.

Few know of the pivotal role that Ian played in the elimination of the bounty system in Canada. Beginning

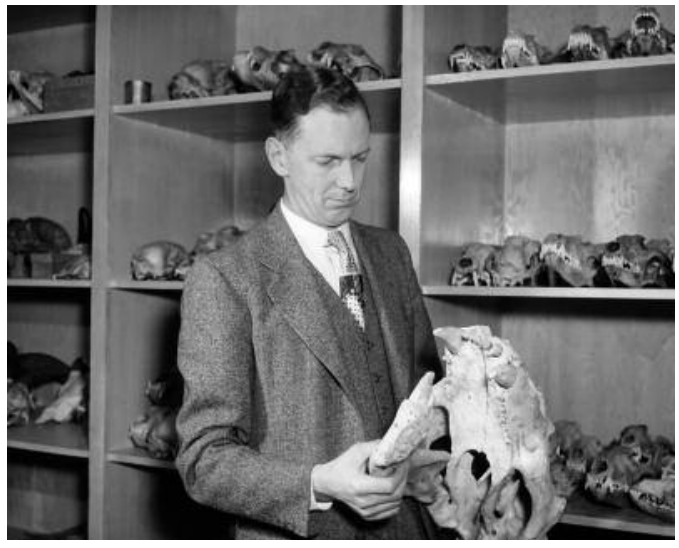

FIGURE 3. Ian with vertebrate skull collection at University of British Columbia, 1951 (University of British Columbia Archives).

in the 1920s, the provinces had systems to reward those who would rid the land of "undesirable" animals or so-called vermin. Some rewards involved cash, some involved gun cartridges. The systems were costly, inefficient and open to widespread abuse. Wolves, cougars, coyotes, Bald Eagles, Golden Eagles, crows, jays and magpies were among the wildlife on the bounty lists. Together with J.R. Dymond, a top Canadian fisheries biologist at the University of Toronto, and armed with good data from both Canada and the United States, they lectured on the folly of the bounty system to hundreds of audiences over nearly 10 years. In the end they prevailed, obtaining strong support from the hunting community. Ian would later recall this victory as "an important step in trying to put scientific management of wildlife into play." By 1973, all Canadian jurisdictions but the Northwest Territories had eliminated the bounty system on wildlife. [Saskatchewan and Nova Scotia have recently implemented limited bounty programs].

Cowan's interests in large mammals and ecology led him to extensive field studies in the Canadian Arctic, the Rocky Mountain National Parks, western Mexico, Scotland, Finland, Africa, Australia, several Pacific Islands and throughout British Columbia. Long before there were computers with electronic search engines, he was highly sought after as an expert advisor on a variety of nature and other issues. In all, his 36 years of formal conservation studies took him to six continents and resulted in over 275 technical and popular publications, being co-author of six teaching films on mammalian behaviour, 110 educational television programs, some 200 radio programs and countless public lectures.

Ian is recognized as a pioneer in the use of television as a medium to provide information to educate the public about conservation and the wonders of the 
natural world. The Fur and Feathers series and The Living Sea series, both produced by the Canadian Broadcasting Corporation (CBC), went to air live. Only The Web of Life series, also a CBC production, was taped.

In the popular Fur and Feathers series of 52 episodes in 1955-56, the approach was to confront a youngster with a natural history object that had never been seen before, and provide facts by responding to the child's questions.

The Web of Life was aired during 1960-63 and used footage from British Columbia, Uganda, southern United States, the Arctic, the Caribbean, and the Gulf of Mexico. In 1963, one of the shows in that series won an award for educational television films at an international television festival.

Although Ian formally "retired" from the University of British Columbia in 1975, his varied interests kept him active on many fronts. One special scientific project involved the consolidation of information on the distribution, abundance and other aspects of the ecology of the bird fauna of British Columbia. It was a sequel to his work with James A. Munro some 40 years earlier. This time though, Ian and the other authors wrote species accounts based on a database of nearly 2 million records contributed by over 11000 volunteers and a bibliography of almost 4700 articles.

Ian made an exceptional contribution to that longterm project, The Birds of British Columbia. His efforts to help initiate the BC Nest Record Scheme that provided vital historical data for the work and his role as one of the authors are well chronicled in the four-volume set. Throughout the more than 20-year term of the project, Ian took on the usual tasks of analyzing data, writing species accounts, and proofing the galleys.

The summarization of the data for Volumes I and II was formidable, each author dealing with the information on thousands of cards that were tabulated manually. The accounts were written in long hand and then turned over to staff at the Canadian Wildlife Service and their word-processing skills.

By the time the authors began Volume III, the personal computer had appeared and they chose to make use of this new technology to help prepare the last two volumes. This meant Ian had to learn the basics of operating a computer along with the database and wordprocessing programs they used to summarize the data and write the species accounts, all of which he did proficiently. He was 82 years of age.

In addition to his author's duties, at the request of the federal and provincial governments, Ian also served for 10 years as the volunteer Chair and project manager for the production of Volumes III and IV.

Managing the activities of the six other authors plus reporting to the federal and provincial Wildlife Directors was a complex and sometimes thankless task. But his leadership paid handsome dividends. Not only were Volumes III and IV of the Birds of British Columbia produced in a timely fashion, they provided the same

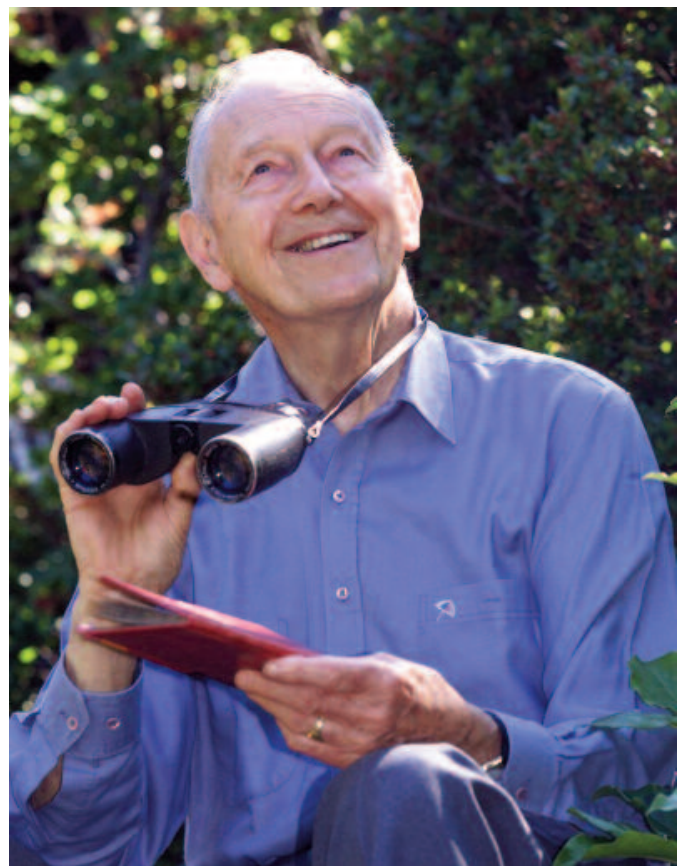

FIGURE 4. Ian birding in his yard and celebrating the release of the $4^{\text {th }}$ and final volume of the Birds of British Columbia, 2001 (Debra Brash/Victoria Times Colonist).

type of comprehensive data that made the first two volumes so valuable and popular. For Volume IV, Ian also wrote more species accounts than any other author as well as being the lead author of the 46-page synopsis, the latter in his $90^{\text {th }}$ year. Volume IV was shortlisted for the 2002 Roderick Haig-Brown Regional British Columbia Book Prize.

As Neil Dawe, a co-author of The Birds of British Columbia noted "I had the good fortune to work with Ian on the project and saw the breadth of his knowledge, far beyond the biological realm, and his significant administrative abilities firsthand. What stuck with me the most, however, was his youthful approach to life and his respectfulness of others no matter their status in life. Ian was always open to new experiences, such as learning to operate a computer in his early 80 s. And new ideas, however unorthodox, were always welcome, indeed encouraged. While he did not necessarily agree with the new concepts, he weighed them carefully, and respectfully challenged them when necessary. His challenges always made one think more carefully and ultimately an improved approach to the issue at hand was the result."

Author/naturalist Bruce Whittington asked Ian in 2001 about his last recorded bird observation. "This morning - a juvenile Cooper's hawk appeared again in the garden. It's banded", Ian said "but I haven't got the number. Not yet, but I will!" At 92, the habits of a scientist were still very much a part of his every day life. 


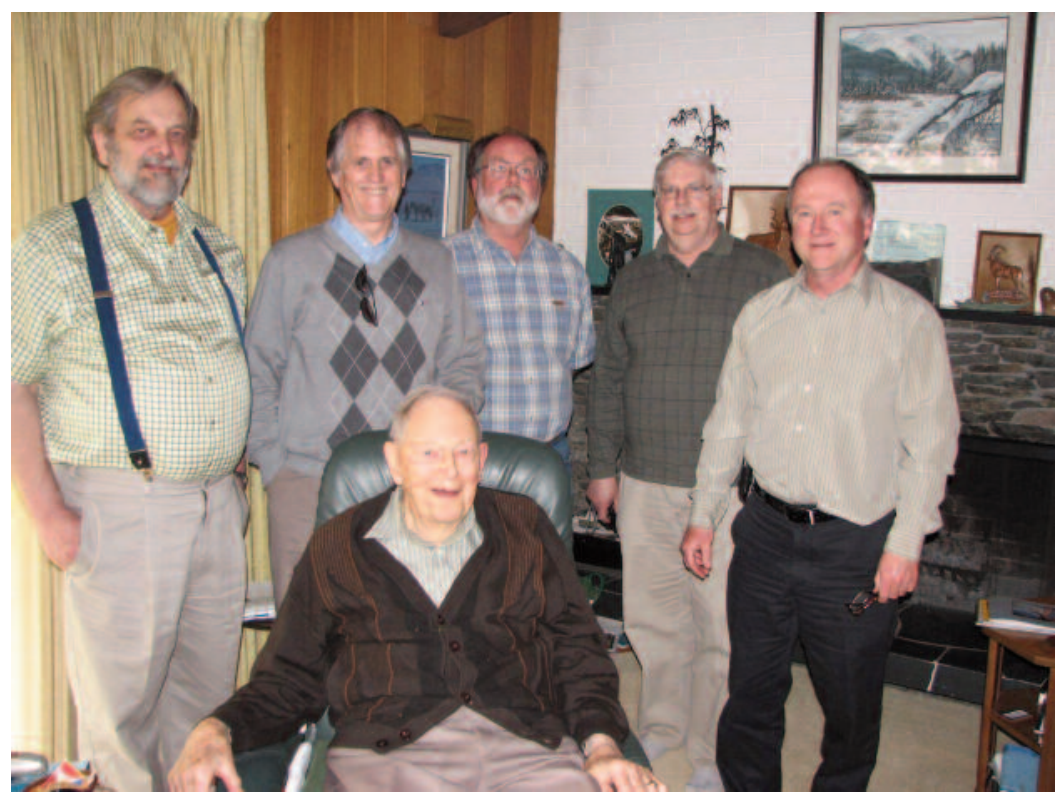

FIgURE 5. The annual Birds of British Columbia "Authors get-together" at the home of Dr. Ian McTaggart-Cowan (seated), 12 April 2010. Standing, from left, Gary W. Kaiser, Neil K. Dawe, Andrew C. Stewart, Michael C.E. McNall, and John M. Cooper (missing: R. W. Campbell). Photo by Brenda Beckstrom.

In the words of long-time friend and colleague, Tom Beck, "even in his 90s, Ian never lost his school-boy enthusiasm for nature".

Ian admitted to being a dedicated collector and museums in several parts of the world now house his collected treasures. His early collections included mammal, bird and plant specimens and the literature of wildlife in the northwest. Later, he focused on kodachrome transparencies, alpine plants, rhododendrons, special ground orchids and award-winning revenue stamps and their legal documents. Always the collections were in search of more information on a topic of interest. The search continued until his death. His learning never stopped.

Ian and his wife Joyce were devoted companions for over 70 years until her passing in 2002. They raised two children, Garry and Ann. Garry (PhD, UBC 1969), a talented fisheries biologist in his own right, was a respected researcher/lecturer at Memorial University, Newfoundland, and coauthored several papers with his father, including the naming of a new species of chiton in 1977. Garry died in 1997. Ann holds a BSc. from UBC (Microbiology/Biology, 1961) and a Masters degree in Canadian Studies (Carleton University, 1964). She is an accomplished pianist and composer. She fondly remembers Ian as a generous and caring husband and father with an enduring sense of humour, extraordinary zeal for exploring the world and a habit, in his latter years, of relaxing with his Hohner Echo harmonica. She also remembers him as a bit of an adventurer who annually navigated his open 6-metre runabout the 30 or so kilometres across the Straight of Georgia from Vancouver to the family's summer stomping grounds on Saturna Island. Three grandchildren and five great grandchildren have benefited from his wisdom and guidance.

Together, Ian and Joyce savoured many of the treasured wild spots of six continents including some 30 trips as invited naturalist hosts, educating guests on Sven Lindblad's ecotourism cruises for Special Expeditions. On early field trips, Joyce paid special attention to data on the occurrence of vegetation, later becoming an expert gardener. A keen and knowledgeable bird observer for all of her life, she kept daily diaries of the visitors to her feeders at their Victoria home. She was, after all, Kenneth Racey's daughter, and natural history was a big part of daily life. Back in the early 1930s, apparently there was more than a small mammal collection that caught Ian's eye in the Racey household.

When Ian was 95, writer Briony Penn asked him about his recipe for living to a good old age:

"Choose your parents very carefully," he said; "find yourself an excellent partner - you can't do it all on your own; eat lots of venison, which you have to get yourself, so you have to climb mountains so you get lots of exercise. And last, but not least, maintain enthusiasm. Enthusiasm is a self-feedback system." 
Ian passed away peacefully on 18 April 2010 surrounded by his family in his Saanich home. He was 2 months shy of his $100^{\text {th }}$ birthday.

Looking back, it was naturalists like Racey and Laing who fed and encouraged Ian's seemingly insatiable initial curiosity of the outdoors. And mentors and contemporaries such as Grinnell, A. Starker Leopold, Dymond, Guiguet and the many other colleagues and students who worked with Ian helped fuel his enthusiasm for exploring the science of that world.

When asked what it is that connected him so passionately to the natural world he said:

\begin{abstract}
"I find it emotionally very satisfying. I think if you spend part of your life alone out in the wild, you are changed. You have a chance to really experience the extraordinary wealth of the creatures around you, and get a heightened sense of imagination and sensitivity to a living community. It doesn't mean that you can't cut a tree or eat a venison steak, it is just understanding the role of each of our lives and how we all fit in" (Penn 2005).
\end{abstract}

That sensitivity to a living community led to an exceptional career in conservation biology and his passion for sharing information led to equally important contributions to education. His lengthy listing of works, awards, distinctions and public service reflects a broad spectrum of interests, and is a testament to his unsurpassed contributions to Canada.

Ian spent his entire life as a learner and educator, the true mark of a Renaissance Man. In his own words, "Evolution is never finished and this applies equally to ideas and to organisms." He never ceased to evolve -as a naturalist, scientist, writer, collector and human being.

Yes, Cowan was indeed, "the real thing."

\section{Awards and Distinctions}

Ian received more awards and distinctions than virtually any other Canadian scientist. These include the Canadian Centennial Medal (1964); the Leopold Medal of the Wildlife Society (1970); Einarsen Award in Conservation by the Northwest Section of the Wildlife Society (1970); Officer of the Order of Canada (1972); Fry Medal of the Canadian Society of Zoologists (1975); Queen Elizabeth Silver Jubilee Medal (1977); the J. Dewey Soper Award (1982, Alberta Society of Professional Biologists); International Conservationist of the Year (1985, American Wildlife Society); Outstanding Achievement Award (1990, Foundation for North American Wild Sheep); Officer of the Order of British Columbia (1991); Doris Huestus Spiers award for Lifetime Achievement (1998, Canadian Society of Ornithologists); and the Ted Barsby Award for Conservationist of the Year (2000, BC Wildlife Federation).

He was an Honorary Life Member and one-time President of the Wildlife Society (1955), Honorary
Life Member and Part President of the Pacific Science Association (1964), Honorary Life Member of the Alberta Society of Professional Biologists (1982) and Association of Professional Biologists of British Columbia (1984), and invited Fellow of the Royal Society of Canada (1946), Fellow of the Arctic Institute of North America (1955), Fellow of the American Association of Advancement of Science (1955), Fellow of the California Academy of Sciences (1955) and an Erskine Fellow (1969, University of Canterbury).

Ian was also, for many years, Honourary President of BC Nature (Federation of British Columbia Naturalists) and Honourary Curator and Research Associate of the Royal BC Museum.

In recognition of his outstanding achievements, he was awarded a Doctor of Environmental Studies by the University of Waterloo (1976), honorary D.Sc. degrees by the University of British Columbia (1977), the University of Victoria (1985) and the University of Northern British Columbia (1997) and LL.D degrees by the University of Alberta (1971) and Simon Fraser University (1981).

In 1988, the Association of Professional Biologists of British Columbia established the Ian McTaggartCowan Award of Excellence in Biology to recognize members who have made outstanding contributions to biology. Former student Daryll Hebert and Birds of BC co-authors Wayne Campbell and Neil Dawe are among the nine recipients to date.

Ian's name is associated with three permanent post-secondary scholarships to assist students in his discipline: The Ian and Joyce McTaggart-Cowan Scholarship at the University of Victoria for outstanding students proceeding to year 3 or 4 of an Honours program in Biology, the Dr. Ian McTaggart-Cowan Scholarship in Environmental Studies for University of Victoria graduate students in the School of Environmental Studies who are focusing on Endangered Species Recovery and/or Ecological Restoration, and the Ian McTaggart-Cowan Scholarship in Wildlife Management at the University of Northern British Columbia.

In addition, the University of Northern British Columbia created the Ian McTaggart-Cowan MuskwaKechika Research Chair (2000) and the University of Victoria established the Ian McTaggart-Cowan Professor of Biodiversity Conservation and Ecological Restoration in its School of Environmental Studies (2005).

The University of Victoria has also named a student residence at its Commonwealth Village in his honour. And in 1992, Ian donated to the University of Northern BC, over 2000 titles from his personal natural history library.

Fittingly, Ian also had an invertebrate species and vertebrate subspecies named in his honour: Cuspidaria cowani, a septibranch bivalve and Microtus townsendii cowani, the Triangle Island subspecies of Townsend's Vole. 


\section{Public Service}

Ian had an outstanding record of public service. As a founding member, he served for seven years (19551962) on the National Research Council of Canada where he was the first Chairman of the Advisory Committee on Wildlife Research. He also served on the Fisheries Research Board of Canada (1954-1965). He was a member and one time Chair of the BC Resources Council (1949-1960), President of the Biological Council of Canada (1966-1968), Chair of the Canadian Environmental Advisory Council (1975-1979), member of the Environmental Protection Board, member of the Arctic Gas Pipeline Board (1973-1976), member of the Arctic Environmental Council (19741976), Chair of the Canadian Committee on Whales and Whaling (1978), and inaugural Chair of the Public Advisory Board of the BC Habitat Conservation Trust Fund (1981). Ian was also active with the City of Vancouver Museum Board (1959-1962), Friends of the Royal BC Museum (1991), a founding director (1971-2002) and Director Emeritus (2002-2010) of The Nature Trust of British Columbia. Ian served as a member of the University of British Columbia Senate for 21 years, Chancellor of the University of Victoria from 1979 to 1984 and was the first Chair of the Academic Council of BC for six years (1976-1982).

Internationally, he was Chair of the Board of Governors of the Arctic Institute of North America (1955); President of the Wildlife Society (1955); Vice President of the International Union for the Conservation of Nature; a member of the Select Committee on National Parks for the United States Secretary of the Interior (1966-1968); Visiting Scientist, CSIRO, Wildlife Division, Canberra Australia (1969-1970); and Chair, National Research Council of the United States

\section{Bibliography of Ian McTaggart-Cowan}

Cowan, I. McT. 1929. Note on Yellow-Bellied Marmot. The Murrelet 10: 64.

Cowan, I. McT. 1930. Mammals of Point Grey. The Canadian Field-Naturalist 44(6): 133-134.

Cowan, I. McT. 1930. Notes on some mammals in British Columbia. The Canadian Field-Naturalist 44: 207.

Cowan, I. McT. 1932. The ecology and life history of the Columbian black-tailed deer, Odocoileus columbianus columbianus, (Richardson) in British Columbia. A Thesis submitted for the degree of Bachelor of Arts in the Department of Zoology, The University of British Columbia, 98 pages.

Cowan, I. McT. 1933. Some notes on the hibernation of Lasionycteris noctivagans. The Canadian Field-Naturalist 48: 74-75.

Cowan, I. McT. 1933. The British Columbia woodchuck Marmota monax petrensis. The Canadian Field-Naturalist 47: 57.
Special Committee on Grizzly Bear Conservation in Yellowstone National Park (1973-1974).

\section{Acknowledgments}

For details and helpful comments, we thank the late Bert Brink, Valerius Geist, the Habitat Conservation Trust Foundation, Daryll Hebert, Charles Krebs, Bill Merilees, The Nature Trust of British Columbia, Ann Schau and Andy Stewart. The production of the extensive bibliography was greatly assisted by Dennis Demarchi, C. Rollins and Ann Schau.

\section{Literature Cited}

Campbell, R. W., D. A. Demarchi, and R. D. Jakimchuk. In preparation. Ian McTaggart Cowan-an enduring legacy of biology, conservation and wildlife management (Celebrating 100 Years with 100 Memories), Biodiversity Centre for Wildlife Studies, Victoria British Columbia.

Corley-Smith, P. 1989. White bears and other curiosities. The first 100 years of the Royal British Columbia Museum. Royal British Columbia Museum, Victoria. 148 pages.

Cowan, I. McT. 1998. Moments from the education of an ornithologist. The Doris Huestus Spiers Lecture, Picoides 11(2): 17-22.

Hatler, D. F., D. W. Nagorsen, and A. M. Beale. 2008. The carnivores of British Columbia. Royal BC Museum Handbook, Volume 5, Mammals of British Columbia. 371 pages.

Mackie, R. 1985. Hamilton Mack Laing: hunter-naturalist. Sono Nis Press, 234 pages.

Penn, B. 2005. The natural history of Ian McTaggart-Cowan. Focus Magazine, Victoria 04-01.

Silver, R. S. 2004. Renaissance man. Discovery_A Journal of the Vancouver Natural History Society, Spring.

Whittington, B. 2001. Ian McTaggart-Cowan-for the birds. Victoria Times Colonist, 12 August page D8.

22 November 2010

Cowan, I. McT. 1933. The mule deer of southern California and northern lower California as a recognizable race. Journal of Mammalogy 14: 326-327.

Cowan, I. McT. 1933. A new race of deer from eastern California. Proceedings of the Biological Society of Washington 46: 67-70.

Cowan, I. McT. 1934. Two cases of pathologic skin growths in deer of the genus Odocoileus. The Murrelet 15: 81-82.

Cowan, I. McT. 1935. A distributional study of the Peromyscus sitkensis group of white-footed mice. University of California Publications in Zoology 40: 429-438.

Cowan, I. McT. 1935. Distribution and variation in deer (Genus Odocoileus) of the Pacific coastal region of North America. University of California, $\mathrm{PhD}$ thesis, 338 pages.

Cowan, I. McT. 1936. Notes on some mammals in the British Columbia Provincial Museum with a list of the type specimens of North American recent mammals in the museum. Canadian Field-Naturalist 50: 145-148.

Cowan, I. McT. 1936. A review of the reptiles and amphibians of British Columbia. British Columbia Museum, 25 pages. 
Cowan, I. McT. 1936. Nesting habits of the flying squirrel, Glaucomys sabrinus. Journal of Mammalogy 17: 58-60.

Cowan, I. McT. 1936. Distribution and variation in deer (genus Odocoileus) of the Pacific coastal region of North America. California Fish and Game 22: 155-246.

Racey, K., and I. McT. Cowan. 1936. Mammals of the Alta Lake Region of south-western British Columbia. In Report of the Provincial Museum. 1935 pages. H15-H29 British Columbia Provincial Museum, Victoria.

Cowan, I. McT. 1937. Additional breeding colonies of the Herring Gull in British Columbia. Murrelet 18(1-2): 28.

Cowan, I. McT. 1937. The distribution of flying squirrels in western British Columbia with the description of a new race. Proceedings of the Biological Society of Washington 50: 77-82.

Cowan, I. McT. 1937. A review of the reptiles and amphibians of British Columbia. Pages 16-25 in Report of the Provincial Museum for 1936, Victoria, British Columbia.

Cowan, I. McT. 1937. The house finch at Victoria British Columbia. Condor 39: 225.

Cowan, I. McT. 1937. A new race of Peromyscus maniculatus from British Columbia. Proceedings of the Biological Society of Washington 50: 215-216.

Cowan, I. McT. 1938. Distribution of turtles in coastal British Columbia. Copeia 1938(2): 91.

Cowan, I. McT. 1938. Distribution of the races of the Williamson Sapsucker in British Columbia. Condor 40(3): $128-129$.

Cowan, I. McT. 1938. Geographic distribution of colour phases of the red fox and black bear in the Pacific Northwest. Journal of Mammalogy 19: 202-206.

Cowan, I. McT. 1938. Nature's children in our western gardens. The Garden Beautiful 7(5): 6-8.

Cowan, I. McT. 1938. Notes on the hares of British Columbia with the description of a new race. Journal of Mammalogy 19: 240-243.

Cowan, I. McT. 1938. The fur trade and the fur cycle: 18251857. British Columbia Historical Quarterly: 19-30.

Cowan, I. McT. 1938. What causes freak antlers? Angler and Hunter Outdoor Magazine. 3 pages.

Cowan, I. McT. 1938. White-tailed Ptarmigan of Vancouver Island. Condor 41: 82-83.

Cowan, I. McT. 1938. Some fish records from the coast of British Columbia. Copeia 1938(2): 97.

Cowan, I. McT. 1939. Black Phoebe in British Columbia. Condor 41: 123.

Cowan, I. McT. 1939. The sharp-headed finner whale of the eastern Pacific. Journal of Mammalogy 20: 215-225.

Cowan, I. McT. 1939. The vertebrate fauna of the Peace River District of British Columbia. Occasional Papers of the British Columbia Provincial Museum, 1: 1-102.

Cowan, I. McT. 1940. Distribution and variation in the native sheep of North America. American Midland Naturalist 24: 505-580.

Cowan, I. McT. 1940. Bird records from British Columbia. Murrelet 21: 69-70.

Cowan, I. McT. 1940. Two apparently fatal grouse diseases. Journal of Wildlife Management 4: 311-312.

Cowan, I. McT. 1940. Winter occurrence of summer birds on Vancouver Island, British Columbia. Condor 42: 213-214.

Cowan, I. McT. 1940. Pentadactyly in a Spotted Sandpiper. The Murrelet 21: 6 .

Cowan, I. McT. 1941. Insularity in the genus Sorex on the north coast of British Columbia. Proceedings of the Biological Society of Washington 54: 95-108.
Cowan, I. McT., and J. Hatter. 1940. Two mammals new to the known fauna of British Columbia. The Murrelet 21: 9.

Cowan, I. McT. 1941. Fossil and subfossil mammals from the Quaternary of British Columbia. Transactions of the Royal Society of Canada 35: 39-50.

Cowan, I. McT. 1941. Longevity of the red-legged frog. Copeia 1941(1): 48.

Cowan, I. McT. 1942. Notes on winter occurrence of bats in British Columbia. The Murrelet 23: 2.

Cowan, I. McT. 1942. Food habits of the Barn Owl in British Columbia. The Murrelet 23(2): 48-53.

Cowan, I. McT. 1942. Report upon some diseases and parasites of game birds and fur-bearing mammals in British Columbia. British Columbia Provincial Game Commission, 6 pages.

Cowan, I. McT. 1942. Economic status of the pheasant on the cultivated lands of the Okanagan Valley. BC Annual Report of the British Columbia Game Commission: 49-62.

Cowan, I. McT. 1942. Some diseases and parasites of game birds and fur-bearing mammals in British Columbia. Pages K40-K45 in Annual Report of the British Columbia Game Commission for 1941. Victoria, British Columbia.

Cowan, I. McT. 1942. Termite-eating by birds in British Columbia. The Auk 59(3): 451.

Cowan, I. McT. 1943. Aspergillosis in a Thayer Gull. The Murrelet 24(2): 29.

Cowan, I. McT. 1943. Notes on the life history and morphology of the Cephenemyia jellisoni (Townsend) and Lipoptena depressa (Say), two dipterous parasites of the Columbia black-tailed deer (Odocoileus hemionus columbianus (Richardson). Canadian Journal of Research D21: 171187.

Cowan, I. McT. 1943. Report on game conditions in Banff, Jasper and Kootenay national parks. Canadian Wildlife Service Report C313, Ottawa. Ontario.

Cowan, I. McT. 1944. Further notes on the winter occurrence of bats in British Columbia. The Murrelet 25: 2

Cowan, I. McT. 1944. The House Finch (Carpodacus mexicanus) in Alberta. The Murrelet 25(3): 45.

Cowan, I. McT. 1944. The Dall porpoise, Phocoenoides dalli (True), of the northern Pacific Ocean. Journal of Mammalogy 25: 205-306.

Cowan, I. McT. 1944. Parasites, diseases and injuries of game animals in Banff, Jasper, and Kootenay National Parks. National Parks Bureau, 48 pages..

Cowan, I. McT., and C. D. Fowle. 1944. Visceral gout in a wild Ruffed Grouse. Journal of Wildlife Management 8(3): 260-261.

Munro, J. A., and I. McT. Cowan. 1944. Preliminary report on the birds and mammals of Kootenay National Park, British Columbia. The Canadian Field-Naturalist 58: 34 51.

Syverton, J. T., and I. McT.Cowan.1944. Bird pox in the Sooty Grouse Dendragapus fuliginosus fuliginosus with recovery of the virus. American Journal of Veterinary Research 16: 215-222.

Cowan, I. McT., and J. A. Munro. 1944 45. Birds and mammals of Revelstoke National Park (Part1). Canadian Alpine Journal 29: 1: 100-121.

Cowan, I. McT. 1945. The free-tailed bat, Tadarida macrotis in British Columbia. The Canadian Field-Naturalist 59: 149.

Cowan, I. McT. 1945. A beaked whale stranded on the coast of British Columbia. Journal of Mammalogy 26: 93-94.

Cowan, I. McT. 1945. The ecological relationships of the food of the Columbian black-tailed deer, Odocoileus hem- 
ionus columbianus (Richardson), in the coast forest region of southern Vancouver Island, British Columbia. Ecological Monographs 15: 109-139.

Cowan, I. McT. 1945. Report of wildlife studies in the Rocky Mountain parks in 1945. Mimeographed report, National Parks Bureau, 34 pages.

Cowan, I. McT. 1945 Standing room only - there's plenty of wildlife in Jasper. Canadian National Magazine, September.

Cowan, I. McT., and G. C. Carl. 1945. The northern elephant seal (Mirounga angustirostris) in British Columbia water and vicinity. The Canadian Field-Naturalist 59(5): $170-172$.

Carl, G. C., and I. McT. Cowan. 1945. Notes on the salamanders of British Columbia. Copeia 1945(1): 43-44.

Carl, G. C., and I. McT. Cowan. 1945. Notes on some frogs and toads of British Columbia. Copeia 1945: 52-53.

Clarke, G. H., and I. McT. Cowan. 1945. Birds of Banff National Park, Alberta. The Canadian Field-Naturalist 59(3): 83-103.

Kendeigh, S.C., L. R. Dice, J. E. Hill, A. Leopold, H. P. Thomsen, R. W. Dexter, W. B. Davis, E. R. Hall, A. L. Nelson, C. Cottam, W. S. Bourn, T. C. Stephens, A. F. Halloran, I. McT. Cowan, F. B. McMurry, W. R. Eadie, and L. W. Wilson. 1945. General Notes. Journal of Mammalogy 26 (1): 86-96.

McCabe, T. T., and I. McT. Cowan. 1945. Peromyscus maniculatus macrorhinus and the problem of insularity. Transactions of the Royal Canadian Institute 25: 117-216.

Cowan, I. McT. 1946. Notes on the distribution of the chipmunks Eutamias in southern British Columbia and the Rocky Mountain region of southern Alberta with descriptions of two new races. Proceedings of the Biological Society of Washington 59: 107-118.

Cowan, I. McT. 1946. Antlered doe mule deer. The Canadian Field-Naturalist 60(1): 11-12.

Cowan, I. McT. 1946. Notes on the distribution of Spizella breweri taverneri. Condor 48(2): 93-94.

Cowan, I. McT. 1946. General report upon wildlife studies in the Rocky Mountain parks in 1946. Mimeographed report, National Parks Bureau, 19 pages.

Cowan, I. McT. 1946. Death of a Trumpeter Swan from multiple parasitism. The Auk 63(2): 248-249.

Cowan, I. McT. 1946. Parasites, diseases, injuries, and anomalies of the Columbian black-tailed deer, Odocoileus hemionus columbianus (Richardson), in British Columbia. Canadian Journal of Research D 24: 71-103.

Cowan, I. McT. 1946. Report of the wildlife studies in 1944 and parasites, diseases and injuries of game animals in the Rocky Mountain national parks, 1942-44. Canadian Wildlife Service Unpublished Report, Ottawa, ON. 19 pages.

Cowan, I. McT., and J. A. Munro. 1946. Birds and mammals of Revelstoke National Park (Part 2). Canadian Alpine Journal 29: 2: 237-256.

Cowan, I. McT., and K. Racey. 1946. A new pika (Genus Ochotona) from British Columbia. Canadian Field-Naturalist 60: 102-104.

Sibley, C. G., H. E. Broadbooks, W. H. Sholes, Jr., I. McT. Cowan, W. P. Taylor, C. Cottam, J. G. Peterson, C. W. Quaintance, R. L. Peterson, B. P. Glass, R. R. Talmadge, H. H. Dill, and L. R. Wolfe. 1946. From Field and Study. The Condor 48(2): 92-97.

Cowan, I. McT. 1947. Range competition between mule deer, bighorn sheep, and elk in Jasper Park, Alberta. Transac- tions of the $12^{\text {th }}$ North American Wildlife Conference 12:5 223-227.

Cowan, I. McT. 1947. The timber wolf in the Rocky Mountain national parks of Canada. Canadian Journal of Research 25: 139-174.

Cowan, I. McT.1947. Waterfowl conditions on the Mackenzie Delta. The Murrelet 29 (2): 21-26.

Cowan, I. McT., and J. A. Munro. 1947. Birds and mammals of Revelstoke National Park. National Parks Bureau, Dept. of Mines and Resources, 100-121; 237-256 (Reprinted from the Canadian Alpine Journal, 29: 1 and 29: 2).

Munro, J. A., and I. McT. Cowan. 1947. A review of the bird fauna of British Columbia. British Columbia Provincial Museum Special Publication 2, 285 pages.

Cowan, I. McT. 1948. The occurrence of the granular tapeworm Echinococcus granulosus in wild game in North America. Journal of Wildlife Management 12(1): 105-106.

Cowan, I. McT. 1948. Scientific research on game and game parasites and diseases in British Columbia. Pages 16-31 in British Columbia Game Department, Proceedings Second Annual Game Convention, Victoria, British Columbia.

Cowan, I. McT. 1948. Waterfowl conditions on the Mackenzie Delta: 1947. Murrelet 29(2): 21-26.

Cowan, I. McT. 1949. A study of hunting in British Columbia. Proceedings Third Annual Game Convention, Victoria, British Columbia: 75-79.

Cowan, I. McT. 1949. Pheasant study in British Columbia in 1948. Pages 112-116 in British Columbia Game Department, Proceedings Third Annual Game Convention, Victoria, British Columbia.

Cowan, I. McT.1949. Rabies as a possible population control of Arctic Canidae. Journal of Mammalogy 30(4): 396-398.

Cowan, I. McT.1949. Preliminary report upon the Sayward Forest deer study, 1948-49. [Unpublished] mimeo, 5 pages.

Cowan, I.McT., and V. C. Brink, 1949. Natural game licks in the Rocky Mountain national parks of Canada. Journal of Mammalogy 30 (4):379-387.

Hatter, J., and I. McT. Cowan. 1949. Waterfowl breeding ground survey in British Columbia. British Columbia Game Commission Memorandum, Victoria, British Columbia. 2 pages.

Gabrielson, I. N., R. P. Allen, I. McT. Cowan, P. A. DuMont, R. H. Pough, and G. A. Swanson. 1949. Report of the A. O. U. Committee on bird protection. The Auk 67(3): 316-324.

Cowan, I. McT. 1950. Some vital statistics of big game on overstocked mountain ranges. Transactions of the North American Wildlife Conference 15: 581-588.

Cowan, I. McT. 1950. Problems of wildlife research and management in the province of British Columbia. Pages 20-27 in British Columbia Game Department, Proceedings Fourth Annual Game Convention, Victoria, British Columbia.

Kendeigh, S. C., H. I. Baldwin, V. H. Cahalane, C. H. D. Clarke, C. Cottam, I. McT. Cowan, P. Dansereau, J. H. Davis, F. W. Emerson, I. T. Haig, A. Hayden, C. L. Hayward, J. M. Linsdale, J. A. MacNab, and J. E. Potzger. 1950-51. Nature sanctuaries in the United States and Canada: A preliminary inventory. The Living Wilderness 15(35): 1-45.

Cowan, I. McT., W. S. Hoar, and J. Hatter. 1950. The effect of forest succession upon the quality and upon the nutritive values of woody plants used as food by moose. Canadian Journal of Research. Section D: Zoological Sciences 28 5: $249-271$ 
Cowan, I. McT., and R. H. Mackay. 1950. Food habits of the marten (Martes americana) in the Rocky Mountain region of Canada. The Canadian Field-Naturalist 64: 100-104.

Cowan, I. McT. 1951. The diseases and parasites of big game mammals of western Canada. In Fifth Annual Game Commission Convention, Victoria, BC: 37-64.

Cowan, I. McT. 1951. Nature sanctuaries in the United States and Canada. Living Wilderness 35: 45 pages.

Cowan, I. McT. 1951. A new Microtus from the western Arctic of Canada. Journal of Mammalogy 32: 353-354.

Cowan, I. McT. 1951. Report on the deer population of Graham Island, Queen Charlotte Islands, British Columbia. British Columbia Game Department Unpublished Report, Victoria, British Columbia.

Cowan, I. McT. 1951. The Passenger Pigeon. Museum and Art Notes 2d series 1: 25-26.

Cowan, I. McT., and W. B. M. Hick. 1951. A comparative study of the mycology of the head region of three species of Thamnophis (Reptilia, Ophidia). Transactions of the Royal Society of Canada 35(3) (5):19-60.

Cowan, I. McT. 1952. Big game in the mountain province. Canadian Geographical Journal XLIV (6): 226-241.

Cowan, I. McT. 1952. Review: Union Bay. (The Life of a City Marsh) by H. W. Higman and E. J. Larrison. Journal of Wildlife Management 16 (1): 102.

Cowan, I. McT. 1952. Review: The elk of North America by O. J. Murie. The Journal of Wildlife Management 16(1): 96-97.

Cowan, I. McT. 1952. Ruts and ridges: some major issues in wildlife conservation. Proceedings of the $6^{\text {th }}$ Annual BC Big Game Convention: 63-68.

Cowan, I. McT. 1952. The role of wildlife on forest land in Western Canada. Forest Chronicles 28: 42-49.

Cowan, I. McT. 1952. Waterfowl at Beacon Hill Park. Victoria Naturalist 9(2): 21-22.

Cowan, I. McT., and C. Guiget. 1952. Three cetacean records from British Columbia. The Murrelet 33(1): 10-11.

Cowan, I. McT., and J. Hatter. 1952. A trap and technique for the capture of diving waterfowl. Journal of Wildlife Management 16 (4): 438-441.

Cowan, I. McT. 1953. Getting wise to our wildlife. C-I-L Oval: 14-17.

Cowan, I. McT. 1953. Review: Birds of Washington State by S.G. Jewett et al. The Canadian Field-Naturalist 69: 29-30.

Cowan, I. McT. 1953. Riistanhoito Kanadassa. Eripainos Sumomen Riista 8: 84-109.

Cowan, I. McT. 1953. Small mammals of the western mountains. Canadian Geographical Journal XLVII (4): 130-141.

Cowan, I. McT. 1954. The distribution of the pikas (Ochotona) in British Columbia and Alberta. The Murrelet 35: 20-24.

Cowan, I. McT. 1954. A new northern record for Xanthus Murrelet, Brachyrhamphus hypoleuca. The Murrelet 35: 50.

Cowan, I. McT. 1954. An indication of population mixing in Canada geese. The Murrelet 35: 45.

Cowan, I. McT. 1954. Observations on wildlife conservation and management in Britain and Norden. British Columbia Game Department, Game Convention, Report of Proceedings 8: 22-30.

Cowan, I. McT. 1954. Review: A herd of mule deer by J. M. Linsdale and P. Q. Tomich. Journal of Wildlife Management 18(2): 274-275.
Cowan, I. McT. 1954. The occurrence of the Pleistocene wolf (Canis dirus) in the Rocky Mountains of Central Alberta. Canadian Field-Naturalist 68(1): 44.

Cowan, I. McT., and M. G. Arsenault. 1954. Reproduction and growth in the creeping vole, Microtus oregoni serpens Merriam. Canadian Journal of Zoology 32: 198-208.

Cowan, I. McT., and M. F. Jackson. 1954. Population dynamics of Barrow's Golden-eye in British Columbiaprogress report. University of British Columbia, Department of Zoology Unpublished Report, Vancouver, British Columbia. 7 pages.

Robinson, D. J., and I. McT. Cowan. 1954. An introduced population of the gray squirrel (Sciurus carolinensis Gmelin) in British Columbia. Canadian Journal of Zoology 32: 61-282.

Cowan, I. McT. 1955. An instance of scabies in the marten (Martes americana). Journal of Wildlife Management 19(4): 499.

Cowan, I. McT. 1955. Birds of Jasper National Park, Alberta, Canada, Canadian Wildlife Service Wildlife Management Bulletin Series 2(8), 66 pages.

Cowan, I. McT. 1955. Chemical sprays and their relation to wildlife. Proceedings of the $9^{\text {th }}$ Annual BC Game Convention, 10 pages.

Cowan, I. McT. 1955. Getting wise to our wildlife. Canadian Nature May-June: 90-97.

Cowan, I. McT. 1955. The challenge we take: appraisal of the $20^{\text {th }}$ North American Wildlife Conference. Transactions of the $20^{\text {th }}$ North American Wildlife Conference: 662-670.

Cowan, I. McT. 1955. Wildlife conservation in Canada. Journal of Wildlife Management 19: 161-176.

Cowan, I. McT. 1955. The wildlife resources in Canada. A brief to the Royal Commission on Canada's Economic Prospects. The Canadian Conservation Association, 34 pages.

Cowan, I. McT. 1955. The Whooping Crane. Bulletin of the Vancouver Natural History Society 95: 2-3.

Cowan, I. McT., and A. J. Wood. 1955. The normal temperature of the Columbian black-tailed deer. Journal of Wildlife Management 19: 154.

Cowan, I. McT., and A. J. Wood. 1955. The growth rate of the black-tailed deer Odocoileus hemionus columbianus. Journal of Wildlife Management 19: 331-336.

Cowan, I. McT. 1956. The gamble of game management. BC Wildlife Review 5 (1): 4-5.

Cowan, I. McT. 1956. Review: The barren ground caribou by F. Harper. Ecology 37(3): 626-627.

Cowan, I. McT. 1956. Review: Prairie Ducks by L. K. Sowls. The Canadian Field-Naturalist 70: 145.

Cowan, I. McT. 1956. What and where are the mule and black-tailed deer? Pages 335-339 in The deer of North America: their history and management. Edited by W. P. Taylor. Stackpole Co. and Wildlife Management Institute, Washington, D.C.

Cowan, I. McT. 1956. Life and times of the coast blacktailed deer. Pages 523- 617 in The deer of North America: their history and management. Edited by W. P. Taylor. Stackpole Co. and Wildlife Management Institute, Washington, D.C.

Bandy, P. J., I. McT. Cowan, W. D. Kitts, and A. J. Wood. 1956. A method for the assessment of the nutritional status of wild ungulates. Canadian Journal of Zoology 34: 48-52. 
Kitts, W. D., I. McT. Cowan, J. Bandy, and A. J. Wood. 1956 The immediate post-natal growth in the Columbian black-tailed deer in relation to the composition of the milk of the doe. Journal of Wildlife Management 20 (2): 212-214.

Manzer, J. I., and I. McT. Cowan. 1956. Northern fur seal in the inside coastal waters of British Columbia. Journal of Mammalogy 37: 83-86.

Cowan, I. McT. 1957. The penalties of ignorance to man's biological independence. Pages 41-50 in Our debt to the future. Edited by E. G. D. Murray. Royal Society of Canada Symposium Presented on the $75^{\text {th }}$ Anniversary of the Royal Society of Canada: 41-50.

Cowan, I. McT., A. J. Wood, and W. D. Kitts. 1957. Feed requirements of deer, beaver, bear, and mink for growth and maintenance. Transactions of the North American Wildlife Conference 22: 179-188.

Edwards, R. Y., and I. McT. Cowan. 1957. Fur production of the boreal forest region of British Columbia. Journal of Wildlife Management 21: 257-267.

Kitts, W. D., R. J. Bose, A. J. Wood, and I. McT. Cowan. 1957. Preliminaxry observations of the digestive enzyme system of the beaver (Castor canadensis). Canadian Journal of Zoology 35: 449-452.

Myres, M. T., I. McT. Cowan, and M. D. F. Udvardy. 1957. The British Columbia Nest Records Scheme. The Condor 59(5): 308-310.

Bandy, P. J., W. D. Kitts, A. J. Wood, and I. McT. Cowan. 1957.The effects of age and the plane of nutrition on the blood chemistry of the Columbian black-tailed deer (Odocoileus hemionus columbiana) B. Blood glucose, nonprotein nitrogen, total plasma protein, plasma albumin, globulin and fibrinogen. Canadian Journal of Zoology 35: 283-289.

Kitts, W. D., M. C. Robertson, B. Stephenson, and I. McT. Cowan. 1958. The normal blood chemistry of the beaver (Castor canadensis), A. packed-cell volume, sedimentation rate, haemoglobin, erythrocyte diameter and blood cell counts. Canadian Journal of Zoology 36: 279-283.

Cowan, I. McT. 1959. Publications review: Survey on the Galapagos Island by I. Eibleibesfeldt. U.N.E.S.C.O. 9: $40-41$.

Steenson, A. B., W. D. Kitts, A. J. Wood, and I. McT. Cowan. 1959. The normal blood chemistry of the beaver (Castor canadensis) B. blood glucose, total protein, albumin, globulin, fibrinogen, non-protein nitrogen, amino acid nitrogen, creatine, cholesterol and volatile fatty acids. Canadian Journal of Zoology 37: 9-14.

Cowan, I. McT. 1960. Sundry thoughts on fishing efficiency: how far can we go? Western Fisheries 59(4): 17-18.

Cowan, I. McT. 1960. Impressions of science in the U.S.S.R. Vancouver Institute Lecture, University of British Columbia, Vancouver, British Columbia.

Cowan, I. McT. 1960. Of mice and men - The biology of Numbers. Vancouver Institute Lecture, University of British Columbia, Vancouver, British Columbia.

Currier, A., W. D. Kitts, and I. McT. Cowan. 1960. Cellulose digestion in the beaver (Castor canadensis). Canadian Journal of Zoology 38: 1109-1116.

Cowan, I. McT. 1961. Of mice and men - Or the biology of numbers. Vancouver Institute Lecture, University of British Columbia, Vancouver, British Columbia.

Cowan, I. McT. 1961. A review of wildlife research in Canada. Resources for Tomorrow Conference 2: 889-899.
Cowan, I. McT., and G. McT. Cowan. 1961. The Amur Barn Swallow off British Columbia. Condor 63: 419.

Cowan, I. McT., and V. Geist. 1961. Aggressive behavior in deer of the genus Odocoileus. Journal of Mammalogy 42(4): 522-526.

Cowan, I. McT., and V. Geist. 1961. The North American wild sheep. Pages 58-83 in North American Big Game. Edited by R. C. Alberts. The Boone and Crockett Club. Pittsburgh, Pensylvannia.

Wood, A. J., H. C. Nordan, and I. McT. Cowan. 1961. The care and management of wild ungulates for experimental purposes. Journal of Wildlife Management 25(3): 295-302.

Fennell, C.W., M. Wallace, J. A. Bruce, R. A. Ryder, L. A. Roper, C. A. Ely, E. Willis, W. C. Hanna, I. McT. Cowan, and G. McT. Cowan. 1961. From field and study. The Condor 63(5): 417-419.

Cowan, I. McT., and P. Johnston. 1962. Blood serum protein variation at the species and subspecies level in deer of the genus Odocoileus. Systematic Zoology 11:131-138.

Cowan, I. McT., H. C. Nordan, and A. J. Wood. 1962. Studies in tranquilization and immobilization of deer. Canadian Journal of Comparative Medicine and Veterinary Science 26(3): 57-61.

Cowan, I. McT. 1962. Hybridization between the black-tail deer and the white-tail deer. Journal of Mammalogy 43(4): 539-541.

Cowan, I. McT. 1962. Molluscs of a single dredge haul. Pacific Northwest Shell News 2(3): 37.

Cowan, I. McT. 1962. Review: A revision of the reindeer and caribou, Genus Rangifer by A. W. F. Banfield, National Museum Bulletin. The Canadian Field-Naturalist 76: 168169.

Krebs, C. J., and I. McT. Cowan. 1962. Growth studies in reindeer fawns. Canadian Journal of Zoology 40(5): 863869.

Nordan, H.C., A. J. Wood, and I. McT. Cowan. 1962. Further studies on immobilization of deer with succinylcholine. Canadian Journal of Comparative Medicine and Veterinary Science 26(10): 246-248.

Wood, A. J., I. McT. Cowan, and H. Nordan. 1962. Periodicity of growth in ungulates as shown by deer of the genus Odocoileus. Canadian Journal of Zoology 40: 593-603.

Cowan, I. McT. 1963. Report of the standing committee of conservation [as Chair]. Proceedings of the $10^{\text {th }}$ Pacific Science Congress: 209-256.

Cowan, I. McT. 1963. Tonicella insignis Reeve in British Columbia. Pacific Northwest Shell News 3(5): 53.

Cowan, I. McT. 1963. The preservation of colour in chitons. Pacific North West Shell News 3(6): 65.

Lewall, E., and I. McT. Cowan. 1963. Age determination in black-tailed deer by degree of ossification of the epiphyseal plate in the long bones. Canadian Journal of Zoology 41: 529-636.

Low, W. A., and I. McT. Cowan. 1963. Age determination of deer by annular structure of dental cementum. Journal of Wildlife Management 27 (3): 466-471.

Stewart, S. F., H. A. Nordan, A. J. Wood, and I. McT. Cowan. 1963. Changes in the plasma lipids of the blacktailed deer throughout a year. XVI International Congress of Zoology 2: 46.

Cowan, I. McT. 1964. A naturalist-scientist's attitude toward national parks. Canadian Audubon May-June: 93-96.

Cowan, I. McT. 1964. The egg capsule and young of Beringius eyerdami Smith (Neptuneidae). Mollusca Gastropoda). The Veliger 7(1): 43-45. 
Cowan, I. McT. 1964. A new species of the Lamellibranch genus Aligena from Western Canada. The Veliger 7(2): 108-109.

Cowan, I. McT. 1964. New information on the distribution of marine mollusca on the coast of British Columbia. The Veliger 7(2): 110-113.

Cowan, I. McT. 1964. The egg capsule and young of the gastropod Pyrulofusus harpa (Morch). Veliger 8(1): 1-2.

Cowan, I. McT. 1964. Report on term research grant: t 152/I. McT. Cowan - study of mammalian adaptation to physical and biotic factors. University of British Columbia, Department of Zoology, Vancouver, British Columbia. 25 pages.

Cowan, I. McT. 1964. Review: Proceedings of the first national white-tailed deer disease symposium by M. F. Baker. Journal of Wildlife Management 28(1): 186-188.

Cowan, I. McT. 1964. Wildlife. Proceedings of the $15^{\text {th }}$ British Columbia Resources Conference: 87-89.

Cowan, I. McT. 1964. The holotype of the Franklin Grouse (Canachites franklinii). Canadian Field-Naturalist 78(2): 127-128.

Cowan, I. McT. 1964. Threatened species of mammals in North America. XVI International Congress of Zoology 8: 17-21.

Cowan, I. McT., and J. H. McLean. 1964. A new species of Puncturella (cranopsis) from the Northeastern Pacific. The Veliger 11(2): 105-108.

Grant, P. R., and I. McT. Cowan. 1964. A review of the avifauna of the Tres Marias Islands, Nayarit, Mexico. The Condor, 66(3): 221-228.

Cowan, I. McT. 1965. A new necessity of the new age - the PhD. UBC Alumni Chronicle Spring: 7-8.

Cowan, I. McT. 1965. Conservation and man's environment. Nature 208 (5016): 1145-1151.

Cowan, I. McT. 1965. Review: Geographical and Sexual Variation in the Long-tailed Jaeger, (Stercorarius longicaudus Vieillot) by T. H. Manning. The Murrelet 46(1): 17.

Cowan, I. McT., and C. J. Guiguet. 1965. The mammals of British Columbia. British Columbia Provincial Museum Handbook 11: 413 pages.

Wood, A. J., I. McT. Cowan, and M. J. Daniel. 1965. Organ weight-body weight relations in the family Mustelidae: the mink (Mustela vision). Canadian Journal of Zoology 43(1): 55-68.

Cowan, I. McT. 1966. Conservation and man's environment. Pages 61-80 in Knowledge Among Men. Eleven essays on science, culture and society commemorating the $200^{\text {th }}$ anniversary of the birth of James Smithson. Simon and Schuster and the Smithsonian Institute.

Cowan, I. McT. 1966. Management, response, and variety. Pages 55-65 in Future Environments of North America Series. Edited by F. F. Darling and J. P. Milton. Garden City, New York: Natural History Press.

Smith, A. G., and I. McT. Cowan. 1966. A new deep-water chiton from the Northeastern Pacific. Occasional Papers of the California Academy of Sciences 56: 1-15.

van Tets, P., and I. McT. Cowan. 1966. Some sources of variation in blood sera of deer (Odocoileus) as revealed by starch-gel electrophoresis. Canadian Journal of Zoology 44(4): 631-647.

Cowan, I. McT. 1967. Man and his environment. Vancouver Institute Lecture, University of British Columbia, Vancouver, British Columbia.

Cowan, I. McT. 1967. Water and wildlife. Proceedings of the $17^{\text {th }}$ British Columbia Resources Conference: 76-81. van Tets, P., and I. McT. Cowan. 1967. The starch-gel electrophoretic serum lipid fraction of two species of deer in the genus Odocoileus. Canadian Journal of Zoology 45(4): $579-581$.

Cowan, I. McT., H. P. Oberlander, P. Larkin, and C.S. Holling. 1968. Man and his environment and doomsday. Vancouver Institute Lecture, University of British Columbia, Vancouver, British Columbia.

Cowan, I. McT. 1968. The role of ecology in the National Parks. Pages 931-939 in The Canadian national parks: today and tomorrow. Edited by J. G. Nelson and R. C. Scace. Studies in Landscape History and Landscape Change. Number 3. National and Provincial Parks Association of Canada and the University Calgary.

Cowan, I. McT. 1968. Wilderness-concept, function and management. The Horace M. Albright Conservation Lectureship, University of California, School of Forestry and Conservation, Berkley, 36 pages. Also in Conservators of hope: the Horace M. Albright lectures, University of Idaho Press, 1988.

Cowan, I. McT. 1968. The interrelationships of certain boreal and Arctic species of Yoldia Moller. The Veliger 11(1): 51-58.

Lykke, J., and I. McT. Cowan. 1968. Moose management and population dynamics on the Scandinavian Peninsula, with special reference to Norway. Proceedings of the North American Moose Workshop 5: 1-22.

Nordan, H. C., I. McT. Cowan, and A. J. Wood. 1968. Nutritional requirements and growth of black-tailed deer, Odocoileus hemionus columbianus, in captivity. Comparative Nutrition of Wild Animals. Proceedings of a symposium, London, 1966. Academic Press, New York. 430 pages.

Wood, A. J., and I. McT. Cowan. 1968 Post natal growth. In A Practical Guide to the Study of the Productivity of Large Herbivores. Edited by Frank B. Goley and Helmut K. Buechner, IBP Handbook Number 7, Blackwell Scientific Publications: 106-113.

Cowan, I. McT. 1969. Ecology and northern development. Arctic 22(1): 3-12.

Cowan, I. McT. 1969. Ecology of north-knowledge is key to sane development. Science Forum 2: 3.

Cowan, I. McT. 1969. Wild values for the future: wild land and the Sportsmen's Federation. The $13^{\text {th }}$ Annual Convention of the British Columbia Wildlife Federation, New Westminster, British Columbia.

Cowan, I. McT. 1969. A new species of gastropod (Fissurellidae, fissurisepta) from the Eastern North Pacific Ocean. The Veliger 12(1): 24-26.

Cowan, I. McT., and P. J. Bandy. 1969. Observations on the hematology of several races of black-tailed deer (Odocoileus hemionus). Canadian Journal of Zoology 47(5): 1021-1024.

Cowan, I. McT., and L. Karstad. 1969. Post-mortem examinations. Pages 251-258 in Wildlife Management Techniques (Third edition, revised). Edited by Robert $\mathrm{H}$. Giles. The Wildlife Society, Washington, DC.

Aleksiuk, M., and I. McT. Cowan. 1969. Aspects of seasonal energy expenditure in the beaver (Castor canadensis Kuhl) at the northern limit of its distribution. Canadian Journal of Zoology 47: 471-481.

Aleksiuk, M., and I. McT. Cowan. 1969. The winter metabolic depression in arctic beavers (Castor canadensis Kuhl) with comparisons to California beavers. Canadian Journal of Zoology 47: 965-979. 
Leopold, S., with C. C. Cottam, I. McT. Cowan, I. N. Gabrielson, and T. L. Kimball. 1969. The National Wildlife Refuge System. Tranactions of the 33rd North American. Wildlife Natural Resources Conference, Washington, D.C.: Wildlife Management Institute: 30-54.

Mosby, H., I. McT.Cowan, and L. Karstad. 1969. Collection and field preservation of biological materials. Pages 259-276 in Wildlife Management Techniques (Third edition, revised). Edited by Robert H. Giles. The Wildlife Society, Washington, D.C.

Taber, R. D., and I. McT. Cowan. 1969. Capturing and marking wild animals. Pages 277-318 in Wildlife Management Techniques (Third edition, revised). Edited by Robert H. Giles. The Wildlife Society, Washington, D.C.

Cowan, I. McT. 1970. Foreword in The Wolf, Ecology and Behavior of an Endangered Species by L. D. Mech, USFWS, Natural History Press, Garden City, New York, 384 pages.

Cowan, I. McT., and W. McCrory. 1970. Variation in the mountain goat, Oreamnos americanus (Blainville). Journal of Mammalogy 51: 60-73.

Ommundsen, P., and I. McT. Cowan. 1970. Development of the Columbian black-tailed deer (Odocoileus hemionus columbianus) during the fetal period. Canadian Journal of Zoology 48(1): 123-132.

Bandy, P. J., I. McT.Cowan, and A. J. Wood. 1970. Comparative growth in four races of black-tailed deer (Odocoileus hemionus). Part I. Growth in body weight. Canadian Journal of Zoology 48: 1401-1410.

Nordan, H. C., I. McT. Cowan, and A. J. Wood. 1970. The feed intake and heat production of the young blacktailed deer (Odocoileus hemionus columbianus). Canadian Journal of Zoology 48(2): 275-282.

Cowan, I. McT. 1971. Summary of the symposium on the status of native cats of North America. Pages 2-8 in Proceedings of symposium on the native cats of North America their status and management. Edited by S. Jorgensen and D. L. Mech. United States Department of the Interior, Portland, Oregon.

Hebert, D. M., and I. McT. Cowan. 1971. Natural salt licks as a part of the ecology of the mountain goat. Canadian Journal of Zoology 49:5-610.

Jonkel, C. J., and I. McT. Cowan. 1971. The black bear in the spruce-fir forest. Wildlife Monograph 27. 57 pages.

Hebert, D. M., and I. McT. Cowan. 1971. White muscle disease in the mountain goat. Journal of Wildlife Management 35(4): 752-756.

Calaby, J. H., H. Henry, and I. McT. Cowan. 1971. The Mountain Pygmy Possum Burramys parvus Broom (Marsupalia) in the Kosciusko National Park, New South Wales. Commonwealth Scientific and Industrial Research Organization, Division of Wildlife Research Technical Paper Number 23, Melbourne, Australia. 11 pages.

Cowan, I. McT. 1972. The status and conservation of bears (Ursidae) of the world - 1970. International Conference on Bear Research and Management 2: 343-367.

Cowan, I. McT., and A. G. Raddi. 1972. Pelage and molt in the black-tailed deer (Odocoileus hemionus (Rafinesque)). Canadian Journal of Zoology 50(5): 639-647.

R. Cathro, G. Collins, I. McT. Cowan, and M. Stutter. 1971. Submission to: The Honourable Jean Chrétien, Minister of Indian Affairs and Northern Development, Ottawa, 6 UBC Law Review 101.
Cowan, I. McT., and W. C. Holloway. 1973. Threatened deer of the world: conservation status. Biological Conservation 5 (4): 243-250.

Cowan, I. McT. 1973. The conservation of Australian waterfowl. Australian Government Publishing Service, Canberra, 83 pages.

Cowan, I. McT. 1973. Review: The Great Barrier Reef by I. Bennett. Pacific Affairs 46(1): 180.

Sirenko, B. I. 1973. Amphipacific distribution of chitons (Loricata) and their new species in the North-West Section of the Pacific Ocean. Zoological Journal, Volume 52(5): 669667, Moscow, USSR. Translated for, and edited by I. McT. Cowan and Allyn G. Smith, published in Of Sea and Shore, Summer 1974, Port Gamble Washington.

Cowan, I. McT. 1974. Keynote address. 1974 Annual Wildlife Diseases Conference, the Wildlife Disease Association, Pacific Grove, California.

Cowan, I. McT. 1974. Management implications of behaviour in the large herbaceous mammals. Pages 921-934 in The behaviour of ungulates and its relation to management. Volume 2. Edited by V. Geist and F. Walther. International Union for Conservation of Nature. New Series Publication 24. Morges, Switzerland.

Cowan, I. McT. 1974: Sabia conica (Schumacher) on the Pacific Coast of North America. The Veliger 16(3): 290.

Cowan, I. McT. 1974. The west American Hipponicidae and the application of Malluvium, Antisabia, and Hipponix as generic names. The Veliger 16(4): 377-382.

Cowan, I. McT., and W. C. Holloway. 1974. Threatened deer of the world: research programs for conservation. Biological Conservation 6 (2): 111-117.

Cowan, I. McT., A. M. Oriordan, and J. S. McT. Cowan. 1974. Energy requirements of the dasyurid marsupial mouse Antechinus swainsonii (Waterhouse). Canadian Journal of Zoology 52: 269-275.

Cowan, I. McT., G. C. Andrew, T. C. Byrne, J. F. Ellis, L. S. Gansner, R. Hughes, J. Patterson, and E. E. Wallach. 1974. Royal Commission on postsecondary education in the Kootenay Region. Queens Printer 2 Volumes.

Johnson, S. R., and I. McT. Cowan. 1974. Thermal adaptation as a factor affecting colonizing success of introduced Sturnidae (Aves) in North America. Canadian Journal of Zoology 52 (12): 1559-1576.

Cowan, I. McT. 1975. Transcript of Mackenzie Valley Pipeline Inquiry, Yellowknife. Awest Reporting Ltd., Burnaby, British Columbia 47: 6267.

Johnson, S. R., and I. McT. Cowan. 1975. The energy cycle and thermal tolerance of the starlings (Aves, Sturnidae) in North America. Canadian Journal of Zoology 53: 55-68.

Thomas, D. C., and I. McT. Cowan. 1975. The pattern of reproduction in female Columbian black-tailed deer, Odocoileus hemionus columbianus. Journal of Reproduction and Fertility 44: 261-272.

Hoefs, M., I. McT. Cowan, and V. J. Krajina. 1975. Phytosociological analysis and synthesis of Sheep Mountain: southwest Yukon Territory, Canada. Syesis 8: 125-228.

Cowan, I. McT. 1976. Foreword in Spatsizi by T. A. (Tommy) Walker. Nunaga Publishing 272 pages.

Haber, G. C., C. J. Walters, and I. McT. Cowan. 1976. Stability properties of wolf-ungulate system in Alaska and management implications. UBC Institute of Animal Resource Ecology, Report R-5-R, 104 pages. 
Cowan, I. McT. 1977. Cumulative impact of development of the Mackenzie Estuary/Delta, NWT. Pages 71-82 in Mackenzie Delta: Priorities and Alternatives. Conference Proceedings, 3-4 December 1975. CARC Ottawa, 193 pages.

Cowan, I. McT. 1977. Natural resources research in Canada's National Parks: An evaluation. Parks Canada, Ottawa, 135 pages.

Cowan, G. McT., and I. McT. Cowan. 1977. New chiton of the genus Mopalia from the northeast Pacific coast. Syesis 10: $45-52$

Elliott, J. P., I. McT. Cowan, and C. S. Holling. 1977. Prey capture by the African lion. Canadian Journal of Zoology 55: 1811-1828.

Cowan, I. McT., and W. C. Holloway. 1978. Geographical location and current conservation status of the threatened deer of the world, Deer Specialist Group of the Survival Service Commission of IUCN. An introductory paper in Threatened Deer. IUCN, Alden Press: 11-20.

Cowan, I. McT., and W. C. Holloway. 1978. Research towards conservation of threatened deer of the world. Pages 329-337 in Threatened deer. International Union for Conservation of Nature and Natural Resources, London, England.

Elliott, J. P., and I. McT. Cowan. 1978. Territoriality, density and prey of lion in Ngorongoro Crater, Tanzania. Canadian Journal of Zoology 56: 1726-1734.

Hoefs, M., and I. McT. Cowan. 1979. Ecological investigation of a population of Dall sheep (Ovis dalli dalli Nelson). Syesis 12 (Supplement 1). 81 pages.

Cowan, I. McT. 1979. Part imperforate stamps in British Columbia. The Canadian Philatelist 30(2): 89-96.

Cowan, I. McT. 1979. New information on the Yukon territorial law stamps. BNA Topics. 36(2): 43-45.

Cowan, I. McT. 1979. The Dawson Mining Court Law stamps of Yukon Territory. BNA Topics 36(3): 50-52.

Bowen, W. D., and I. McT. Cowan, 1980. Scent marking in coyotes. Canadian Journal of Zoology 58: 473-480.

Cowan, I. McT. 1980. The basis of endangerment. Pages 320 in Proceedings of Threatened and endangered species and habitats in British Columbia and Yukon. R. StaceSmith, L. Johns, and P. Joslin. BC Fish and Wildlife Branch, Ministry of Environment. 320 pages.

Cowan, I. McT. 1980. The impact of land use policy in western Canada upon wildlife, 1945 to 1980. Pages 133-170 in Alberta Society of Professional Biologiests, April 22-23, 1980. Symposium on environmental management strategies: past, present and future. Edmonton, Alberta. The Alberta Society of Professional Biologists and Alberta Environment, Edmonton, Alberta. 293 pages.

Cowan, I. McT. 1981. Wildlife conservation issues in northern Canada. Canadian Environmental Advisory Council. Report 11, 30 pages.

Cowan, I. McT. 1982. Faunal diversity as a habitat goal. Pages 20-130 in British Columbia land for wildlife past, present and future. Edited by D. Day and R. Stace-Smith. Proceedings of Land for Wildlife Symposium, Simon Fraser University, BC Ministry of Environment.

Cowan, I. McT. 1984. Some environmental considerations in the planning, construction, and maintenance of northern roads, with relevance to the MacKenzie Valley Highway. In J. Keith Fraser \& Canadian Environmental Advisory Council. Selected papers from assemblies of the environment councils of Canada, 1975-1980 Canadian Environmental Advisory Council, Ottawa.
Cowan, I. McT. 1985. Forestry and forest wildlife, a conference overview. The Forestry Chronicle 61(2): 200-202.

French, R. D., E. Richardson, D. van Oudeno, L. J. LaFrance, T. W. Turner, H. A. Clampett, J. Lehr, J. Schonfeld, C. Emery, W. Rockett, M. O. Bakker, and I. McT.Cowan. Editors. 1954-1985. Revenue group news, revenue stamps. BNA Topics 11(5) to 42(5).

Cowan, I. McT. 1987. Science and the conservation of wildlife in British Columbia. In Our Wildlife Heritage - 100 years of wildlife management, Edited by A. Murray. Centennial Wildlife Society of British Columbia: 85-106.

Cowan, I. McT. 1987. The marine mammals of British Columbia, their status and distribution. Pages 95-104 in The wildlife of northern British Columbia - past, present and future: the proceedings of a symposium, November 1987. Spatsizi Association for Biological Research, Smithers British Columbia.

Lindblad, S. O., and L. Lindblad. Editors. With contributions from G. Lindsay, I. McT. Cowan, and D. Cornejo. 1987. Baja California. Rizzoli, 184 pages.

Cowan, I. McT., and T. Beck. 1988. Volume 4 in Canadian Encyclopedia. Editor in chief James H. Marsh. Hurtig Publishers, Edmonton, Alberta.

Cowan, I. McT. 1989. Birds and mammals on the Queen Charlotte Islands. Pages 175-186 in The Outer Shores. Edited by G. G. E. Scudder and N. Gessler. Queen Charlotte Islands Museum, Skidegate.

Cowan, I. McT. 1989. Room at the top? Pages 249-266 in Endangered Spaces: the future for Canada's wilderness. Edited by M. Hummel Key Porter Books, Ltd, Toronto.

Cowan, I. McT. 1990. The day before the show. Vancouver Island Rock and Alpine Garden Society newsletter, (March 1990): 1-3.

Campbell, R. W., N. K. Dawe, I. McT. Cowan, J. M. Cooper, G. K. Kaiser, and M. C. E. McNall. 1990. The birds of British Columbia, Volume I. Introduction and Loons through Waterfowl. Royal British Columbia Museum; Environment Canada, Canadian Wildlife Service, Victoria, British Columbia; [Ottawa, Ontario] 514 pages.

Campbell, R. W., N. K. Dawe, I. McT. Cowan, J. M. Cooper, G. K. Kaiser, and M. C. E. McNall. 1990. The birds of British Columbia, Volume II. Diurnal Birds of Prey through Woodpeckers. Royal British Columbia Museum; Environment Canada, Canadian Wildlife Service, Victoria, British Columbia [Ottawa, Ontario], 636 pages.

Hummel, M., and I. McT. Cowan. 1990. Conservation strategy for large carnivores in Canada. World Wildlife Fund Canada, Toronto, Ontario. 98 pages.

Cowan, I. McT. 1991. Foreword. Pages $v-v i$ in Wild hunters — predators in peril by Monte Hummel and Sherry Pettigrew. Key Porter Books, Toronto, Ontario. 244 pages

Cowan, I. McT. 1992. Capture and maintenance of cetaceans in Canada. A report prepared by the Advisory Committee on Marine Mammals. Report to the Minister, Fisheries and Oceans, Ottawa. 30 November.

Geist, V., and I. McT. Cowan.1995. Wildlife conservation policy, Detselig Enterprises, 308 pages.

Cowan, I. McT. 1996. Conservation and man's environment. Parks and Recreation 3(2).

Campbell, R. W., N. K. Dawe, I. McT. Cowan, J. M. Cooper, G. K. Kaiser, M. C. E. McNall, and G. E. John Smith. 1997. The birds of British Columbia, Volume III. Passerines, Flycatchers through Vireos. University of British Columbia Press, 693 pages. 
Cowan, I. McT. 1998. Moments from the education of an ornithologist. The Doris Huestus Spiers Lecture, Picoides 11(2): 17-22.

Kennedy, E., and I. McT. Cowan. 1998. Sixteen years with a Bald Eagle's, Haliaeetus leucocephalus, nest. Canadian Field-Naturalist 112(4): 704-706.

Campbell, R. W., N. K. Dawe, I. McT.Cowan, J. M. Cooper, G. W. Kaiser, A. C. Stewart, and M. C. E. McNall. 2001. The birds of British Columbia: Volume IV: passerines (wood-warblers through Old World sparrows). University of British Columbia Press, Vancouver British Columbia. 739 pages.

Cowan, I. McT., N. K. Dawe, R. W. Campbell and A. C. Stewart. 2001. Avian biodiversity, ecological distribution, and patterns of change. Pages 633-678 in The birds of British Columbia: Volume 4: passerines (wood-warblers through Old World sparrows) by R. W. Campbell, N. K. Dawe, I. McT. Cowan, J. M. Cooper, G. W. Kaiser, A. C. Stewart, and M. C. E. McNall. University of British Columbia Press, 739 pp.

Dawe, N. K., I. McT. Cowan, R. W. Campbell, and A. C. Stewart. 2001. What lies in store for the birds of British Columbia? New philosophies, concerns, and conservation challenges. Pages 679-695 in The birds of British Columbia:
Volume 4: passerines (wood-warblers through Old World sparrows) by R. W. Campbell, N. K. Dawe, I. McT. Cowan, J. M. Cooper, G.W. Kaiser, A.C. Stewart and M. C. E. McNall. University of British Columbia Press. 739 pages.

Cowan, I. McT. 2001. Biology of the desert. Presentation to the Victoria Rhododendron Society.

Cowan, I. McT. 2004. The law stamps of Yukon, 1902-1971. The British North America Philatelic Society (BNAPS) Exhibit Series 33:104 pages.

Cowan, I. McT. 2005. The law stamps of British Columbia and their uses 1879-1984. The British North America Philatelic Society (BNAPS) Exhibit Series 36: 170 pages.

Cowan, I. McT. 2005. Foreword. Page IV in James Sirois. 2005. Grizzly chronicles of the Dean \& Kimsquit rivers, British Columbia. Skookum Press, Hagensbourg, BC. 272 pages.

Cowan, I. McT. 2006. Foreword in The Nature Trust of British Columbia - Over 35 Years of Conservation, 96 pages.

Cowan, I. McT. 2010. Badger, Marten, Mink, Otter, Sea Otter, Seal, and Skunk. In The Canadian Encyclopaedia. [online] http://www.thecanadianencyclopedia.com.

Accepted 15 December 2010 